\title{
Europe 1992: Threat or opportunity for the Canadian forest products industry and implications for public policy
}

\author{
by W.T. Stanbury ${ }^{1}$, Ilan Vertinsky ${ }^{2}$, and John L. Howard, Q.C ${ }^{3}$
}

\section{Abstract}

Structural and regulatory changes in Europe are expected to have major implications for the forest products industry and forestry in Canada. In this paper, the changes associated with the completion of the internal market of the European Community, the introduction of a new European forest policy, and structural, political and economic changes in eastern Europe are surveyed and their impacts on the demand and supply of forest products analyzed. The paper also explores the appropriate strategic responses of Canadian firms. The paper concludes with the implications of the political and economic changes brought about by Europe 1992 for public policy.

\section{Résumé}

Les changements dans les structures et les règlements en Europe devraient avoir des implications majeures sur l'industrie des produits forestiers et la foresterie au Canada. Dans cet exposé, les changements associés à la finalisation du marché interne de la Communauté économique, l'introduction d'une nouvelle politique forestière européenne, et les changements des structures, des politiques et de l'économie de l'Europe de l'Est sont étudiés et leurs impacts sur la demande et l'offre de produits forestiers sont analysés. Cet exposé explore aussi les réponses stratégiques appropriées de la part des entreprises canadiennes. L'exposé conclut sur les implications des changements politiques et économiques amenés par l'Europe de 1992 au niveau des politiques publiques.

\subsection{Introduction}

"Europe 1992", is a phrase that is used to refer to the process of "completing the internal market" of 325 million people in the 12 member states ${ }^{1}$ of the European Economic Community (now called the European Community or EC). In 1987, the Treaty of Rome was modified by the Single European Act, which aimed to simplify and augment the Community's decision-making process by extending the influence of the European Parliament and easing the restrictions imposed on the main process by extending the influence of the European Parliament and easing the restrictions imposed on the main legislative body of the EC, the Council of Ministers.

By the end of 1992, the EC must make several hundred legislative and regulatory changes to obtain the free flow of products, capital and people across the national borders of its 12 nations to effect what amounts to the most massive deregulation in history.

The scope of the changes that are to be made by the end of 1992 is enormous. The European Council's White Paper of 1985 set in motion a process requiring the approval of some 279 directives.

The barriers targeted for elimination fall into the following categories: border controls; restrictions on the recognition of professional qualifications granted by other member states; differences among member states in value added and excise taxes; differences in legal regimes; restrictions on the free movement of capital; restrictions on the provision of services; differences

\footnotetext{
${ }^{1}$ UPS Foundation Professor of Regulation and Competition Poiicy, Faculty of Commerce \& Business Administration, University of British Columbia, Vancouver, B.C.

${ }^{2}$ Director, Forest Economics and Policy Analysis Research Unit, and the Center for International Business Studies, University of British Columbia, Vancouver, B.C.

${ }^{3}$ Senior Vice-President, Law and Corporate Affairs, MacMillan Bloedel Ltd., Vancouver, B.C.
}

in regulations and technical standards; and restrictions in public procurement markets. Although the White Paper proposals have been presented as an inseparable package, with no priorities indicated, in fact the key areas are elimination of border controls (the most visible indication of a fragmented market), liberalization of capital movements and services, harmonization of regulations and standards, and the opening of public procurement markets (which account for as much as 15 percent of the EC's gross domestic product) (Calingaert 1988).

By the fall of 1989 , of the directives only 47 had yet to be submitted to the EC Commission. More than half of the 232 proposals made to the Council of Ministers had already been approved (Union Bank of Switzerland 1989). To meet the 1992 target, all the measures must be adopted by the Council by the end of 1990 so that member states have two years to translate the measures into national legislation.

The expected benefits of Europe 1992 include a 6\% decline in prices within five or six years and a major reduction in the unemployment rate. The EC countries are estimated to save at least U.S. $\$ 200$ billion by removing trade barriers, add about $5 \%$ to their collective GDP and create 2.3 million new jobs. A substantially higher growth rate is also predicted.

The EC is the world's largest trading group, accounting for nearly $30 \%$ of the value of world trade (Minshull 1985). Over $35 \%$ of imports into the EEC are of raw materials and foodstuffs, while almost $65 \%$ are manufactured goods. Approximately $80 \%$ of exports are manufactured goods and $20 \%$ are primary products (Minshull 1985). In 1988 the gross national product of the EC was $\$ 4,727$ billion as compared to $\$ 4,796$ billion for the U.S. and $\$ 2,841$ billion for Japan (Union Bank of Switzerland 1989). However, in the 1980s the EC suffered slower growth and higher unemployment than the U.S. and Japan. Moreover, the EC's share of world

\footnotetext{
${ }^{1}$ Belgium, Denmark, France, Germany, Greece, Ireland, Italy, Luxemburg, Portugal, Spain, the Netherlands, United Kingdom.
} 
exports of high-technology products fell substantially between 1979 and 1986. These developments helped to stimulate the desire to complete the internal market.

The EC relies more on international trade than either Japan or the U.S.; imports equal $23 \%$ of the GNP of the EC. Twoway trade between the EC and Canada totalled $\$ 25$ billion in 1989 while that between the EC and the U.S. was $\$ 170$ billion. Over $30 \%$ of all Canadian exports to the EC are forest products. These exports are worth more than $\$ 3.3$ billion. The EC (12\%) is Canada's second largest market for forest products after the U.S. (71\%). In 1989, the value of forest products exports to the EC by type was estimated to be as follows:

- wood pulp
- neftwood lumber
- fine paper
- plywood

- plywood

\begin{abstract}
$\$ 1980$ million
$\$ 670$ million

\$304 million

$\$ 170$ million

$\$ 60$ million
\end{abstract}

Canada supplies $17 \%$ of EC forest products imports ( $\$ 12.5$ billion). With more advantageous access to the market, Nordic countries supply $49 \%$. Canada accounts for $22 \%$ of the EC's imports of wood pulp (total $\$ 6.1$ billion) vs. $39 \%$ from Nordic countries, and $18 \%$ from the U.S. Canada accounts for $14 \%$ of EC imports of newsprint (total $\$ 2.3$ billion) and $10 \%$ of EC imports of lumber (total $\$ 4.1$ billion) (External Affairs and International Trade Canada (EAITC) 1990). Trade with the EC is significant for all regions of Canada including the West Coast. The EC purchases, for example, $40 \%$ of B.C.'s overseas shipments of lumber and $80 \%$ of its overseas plywood shipments (McKeen 1990).

Almost $90 \%$ of imports of pulp, paper and board by the EC enter duty-free. Pulp is entirely duty-free. In 1987 the EC's net external deficit in paper and board was 11.3 million tonnes ( 6.6 billion ECUs). Import penetration is highest for newsprint $(60 \%)$ and kraftliner (77\%) which account for $41 \%$ of all EC pulp, paper and board imports from third countries (EAITC 1990).

The EC is by far the world's largest outlet for market pulp (39\% of world trade in 1987). Imports account for $74 \%$ of EC consumption. Yet some 830 companies were active in the industry in 1987, operating a total of 1032 pulp, paper or board mills in 1987 (EAITC 1990).

For non-EFTA ${ }^{2}$ exporters of newsprint and other paper, duty-free access to the EC is limited to 650,000 tonnes (t), of which $600,000 \mathrm{t}$ has been set aside for Canada. A tariff of $9 \%$ applies on unwaterlined paper imports above the quota. In 1989, the quota was exceeded for the first time $(670,000 \mathrm{t})$. At the behest of EC publishers, the quota was increased by $80,000 \mathrm{t}$, of which $30,000 \mathrm{t}$ was allocated to Canada (EAITC 1990).

Newsprint producers have reason to be concerned about two non-tariff issues: the EC's desire for a waterlining requirement in newsprint (which is usually unacceptable to

\footnotetext{
$\overline{{ }^{2} \text { The European Free Trade Area, formed in 1959, is not a customs union }}$ but a loose association of states (Sweden, Norway, Finland, Austria, Iceland, Switzerland) with the limited aim of abolishing all tariffs on industrial goods between member states. EFTA was seen as "as means of expanding trade and ensuring that a broad alignment in tariff reductions was kept in line with that of the EEC"' (Minshull 1985).
}

publishers), and the new definitions of newsprint which includes surface smoothness and mechanical pulp furnish requirements even though there are no internationally accepted methods of testing the pulp content of paper.

While unprocessed wood enters the EC duty-free, planned lumber is subject to $4 \%$ duty and window and door frames are hit with a $6 \%$ duty. A significant portion of Canadian lumber shipped to the U.K. is rough. Some $60 \%$ of Canadian lumber exported to the EC is destined for the U.K.

The general effect of Europe 1992 will be a shift in the centre of decision making from the national level to the EC level in respect of many matters of concern to business. These include legislation on environmental issues, product definition, technical standards, the free movement of people, free movement of capital, a free market in transportation, competition policy and intellectual property matters.

Canadian industry will be affected by the competition of firms inside the EC through three main channels: through changes in external trade with the EC; through changes in the business environment for Canadian firms operating in the EC; and through changes in the competitiveness and agressiveness of European firms in both their own and the Canadian market. Changes in the relationship between the EC and other countries, particularly EFTA countries ${ }^{3}$, will also have an important impact on Canadian industry where their rivals are located in an EFTA country.

The objective of this paper is to review some of the most significant changes which are likely to be brought about by Europe 1992 as well as some other major changes in Europe which may magnify both the uncertainties for the Canadian forest product industry and the threats and opportunities it faces in Europe. We begin in Section 2 with a brief review of the major areas in which Europe 1992 could affect the Canadian forest products industry. Section 3 examines the potential importance of EC-EFTA relations and the position of Canada's rivals as suppliers of forest products to the EC. Section 4 considers some implications of recent changes in Eastern Europe, including the Soviet Union. Section 5 reviews some of the effects of strategic behaviour by forest products firms in the EC. Section 6 deals with the possibility that Europe 1992 will also result in "Fortress Europe." Section 7 outlines very briefly possible corporate strategies in dealing with Europe 1992. Finally, Section 8 considers some of the implications for public policy.

\subsection{Impact of Europe 1992 on the Canadian forest products industry}

\subsection{Product Standards: Threat or Opportunity?}

If tariffs and quotas are reduced, product standards are likely to become a battleground for both nationalists and those interested in imposing restraints on competition by inhibiting international trade. Moreover, the process by which

\footnotetext{
$\overline{{ }^{3} \text { The EC extended to EFTA countries, along with selected African and }}$ eastern Mediterranean Basin countries, unrestricted access to Community markets for industrial goods, customs preferences for certain agricultural products, and financial aid when needed (Minshull 1985). The EC and EFTA maintain a range of treaties assuring the free passage of goods betwen them, co-operating on common trading standards, rules of origin, and research and development products. The Luxembourg declartion, which became effective in January 1988, provides for further easing of bilateral tariffs and customs formalities between the two groups (Western European Economic Handbook 1987).
} 
harmonization of standards is to occur is highly complex and not always accessible to firms/nations that export into the EC.

While EC standards are to replace existing national standards, some of the member countries will be slow to adopt new European standards and many standards have yet to be agreed upon by all of the members. Hence the movement towards a harmonization of standards in the EC will be slow and the timing and nature of changes in standards unpredictable. It is quite likely that the harmonization process will not be completed by the end of 1992 . Therefore, exporters will have to cope with a mixture of the old and new.

In the past, the basic principle with respect to product standards in the EC has been "mutual recognition", i.e., a product that meets one country's national standards must be allowed to circulate freely with the $\mathrm{EC}^{4}$. However, as the EC becomes one market in 1992, there will be one nonmandatory standard established by the Comité Européan de Normalisation (CEN) and CENELEC (which deals with electrical components), developed from "essential requirements", for health, safety, environment or consumer protection. In theory, a Canadian supplier with another standard can apply to have its products tested to determine if they meet the "essential" requirements of the EC. However, "games" could be played in determining whether non-EC countries meet EC standards. This might take the form of requiring reciprocal recognition of lab/certification processes. Further, local and national government procurement policies could constitute a barrier against suppliers from other EC countries and non-EC countries. Note also there is an early warning system if an EC member state wants to introduce new standards or technical regulations.

On the other hand, even if the EC-wide product and technical standards are unique in all the world, the absolute size of the market (in terms of population and GNP per capita) will likely make it worthwhile to meet them (by special runs if necessary).

It is likely that the differences among EC members' standards will be resolved by "levelling up" to those of the larger and more economically powerful members (e.g., Germany, France and the U.K.)

\section{Standards-setting Process}

The European standards are determined by European bodies with no direct participation from outside countries. Some of Canada's major competitors in the European lumber products market, the Scandinavian ${ }^{5}$ countries which belong to the EFTA, as well as Germany and France (in terms of saw milling), all have direct input into the committees setting EC standards, whereas Canada does not. Canada's competitors will try to impose their own standards, and they will want standards that make it easy for them to supply the

\footnotetext{
${ }^{4}$ In its October 1988 position paper on the external aspects of 1992 , the Commission of the European Communities argued that the EC already applies the GATT code on norms. It gives outside suppliers the same access to national certification procedures as local firms. The position paper added that the EC could recognize tests and certificates issued by third countries as the equivalent of its own systems, but such mutual recognition would have to be negotiated by Brussels and not by individual member countries (Canada, Dept. of External Affairs, 1989)

${ }^{5}$ The Scandinavians have to cope with a forest base that is much more constrained than that in Canada and with relatively high fibre costs. Hence, they are interested in higher quality, more specialized products. They want higher, more stringent standards which might hurt Canadian producers.
}

EC market, but which will be disadvantageous for their competitors such as Canada.

The institutions and the process have been described as follows:

...the European Community adopted a construction directive designed to establish essential requirements to which all construction projects and the products which make up the structure must comply. The six essential requirements are mechanical resistance and stability, safety in case of fire, hygiene, health and the environment, safety in use, protection against noise and energy economy and heat retention. The directive also establishes the ground rules for the development and implementation of harmonized European standards for construction products and gives general direction as to how other products will be certified as meeting the essential requirements.

The directive calls for the establishment of a standing committee for construction made up of [at least] two representatives from each member state charged with the responsibility of overseeing the implementation of the directive and its related "interpretive documents" which includes the harmonized standards. The standing committee will also have technical committees of experts (distinct from the technical committees of CEN) from which it can seek advice. Provision is also made for the standing committee to give mandates to European organizations to develop the actual standards. In virtually all cases these mandates will be given to CEN [which is] European wide and its membership includes countries outside the European Community. $\mathrm{CEN}$ has also been given a mandate to finalize the drafting of the Eurocodes.

There are nine Eurocodes in total being developed, one for each of the basic construction materials such as steel, concrete, masonry and wood with other codes designed to cover the combinations and other general building materials...

...Eurocode Five [which] deals with "timber structures", ...has been developed as an LSD (limit states design) code... While the Eurocodes will not be mandatory, except in the field of public procurement, it is envisaged by the Community that over time they will become the accepted building norm as any structure built in accordance with a Eurocode will be deemed to meet the essential requirements in the construction directive (Bird 1989).

The EC has requested CEN to draft standards in support of the Construction Products Directive. When CEN standards are adopted, ${ }^{6}$ national standards cannot be inconsistent with them. The work of CEN with respect to wood products is being carried on through five technical committees.

\footnotetext{
${ }^{6}$ In the spring of 1989 , a CEN committee was established to develop standards with respect to paper. It is expected that they will relate more to specifications such as size, thickness and to uniform testing procedures than to performance requirements. However, this may depend on the grade of paper or board and the extent of safety and health factors in any particular application. There was acknowledgement that product requirements can vary substantially between customers, and that manufacturers will produce products to customer requirements.
} 
Role of Canadian Industries in Standards-setting Process

Because Canadian forest products firms do not have direct input in or access to the standards-setting committee, ${ }^{7}$ they need to find allies, i.e., European countries who are sympathetic to the needs of Canadian suppliers, primarily those who want to maintain a multi-country supply base for wood products. Potential allies include Britain, Holland, Denmark, Belgium and to a lesser extent Greece and Italy - depending on the specific issue. Further, Canadian firms need offices in Europe, for a presence in Europe allows better access to discussions about the new European standards. A physical presence also increases the effectiveness of lobbying efforts. The Council of Forest Industries (COFI), for example, has four offices in Europe. Because of the technical expertise of COFI, it plays a direct and indirect role in informing those representing consumer interests in the standards-making process.

In addition, the government has an important role of monitoring and developing policy to deal with Europe 1992. The Wood Products Committee in Ottawa plays a role in monitoring developments, formulating policy, and exerting pressure on EC organizations to make their standards-setting process more open.

Canadian firms exporting to Europe need the machinery to ensure that they speak with one voice and pursue a unified Canadian policy. They have used the COFI office in London as the focal point for establishing the Canadian "game plan" and it is the centre of control. ${ }^{8}$ Communications by various lumber product industry groups such as the Bureau de Promotion des Industries du Bois (BPIB) with London is done through the COFI office to ensure a consistent Canadian position. The basic goal of the effort is to make sure that Canadian wood products are accepted in Eurocodes or at least that information about new standards is available immediately. To allow firms with stakes in the European market to develop their strategic plans, there is a need to develop alternative scenarios for the types of standards which may be adopted, so that firms can adapt quickly to whatever outcome occurs. Of particular importance are changes in standards that would require notable capital expenditures (e.g., kiln drying facilities). These usually also take considerable time to put in place. ${ }^{9}$

Consumer interests might influence the standards-setting process. For example, in the matter of green versus kilndried lumber, Europeans must balance their preference for dry lumber against their preference for cheap lumber. Many European suppliers produce lumber that must be dried before it can be used. Canada can supply good green lumber at a cheaper price, and some European buyers prefer to buy the green lumber rather than to pay the premium for drying,

\footnotetext{
${ }^{7}$ Canada's ambassador to the EC Daniel Molgat (1990) argues that the EC " is making every effort to make the standards-setting exercise transparent. They have agreed to share all draft standards with Canada... and have agreed to receive comment from the Standards Council [of Canada] during the six-month review period.'

${ }^{8}$ Both the Canadian government and regional lumber associations (e.g., BPIB) have agreed that COFI should take a lead role in Europe 1992 on behalf of the entire Canadian wood products industry. COFI's experienced staff has maintained close contact with all the key delegations and the technical committees addressing product standards.

${ }^{9}$ McKeen (1990) predicts that all of Europe 1992 will not be in place by the January 1, 1992 deadline. While standards may be written and approved in 1991, it may take several years before they are adopted throughout the EC.
}

although for some uses dried lumber is necessary. European suppliers want to ban imports of green lumber to protect their markets. They have raised the spectre of a threat to their forests from pinewood nematode, but Canadian producers believe Europeans greatly exaggerate the risk. ${ }^{10}$ If kiln drying is made mandatory across the EC, this could have a significant impact on the competitiveness of lumber imports from Canada in the EC and on the ability of different regions of Canada, for example the coastal industry in British Columbia, to supply certain products to the European market (EAITC 1990). Ambassador Molgat (1990) notes that "every effort is being made to have the EC accept the enhanced Canadian mill certificate, or at least give it a trial run." In his view, even if kiln drying is not required for reasons of plant health, "the market will demand kiln-dried products at least in the construction grades."

Effective January 1, 1990 the EC Plant Health Standing Committee decided to require kiln drying of all lumber sold in the EC. However, this requirement applied to Canada only on January 1, 1991.

Because of the importance of Canadian lumber products to the U.K., ${ }^{11}$ Canada has played an important role in determining the U.K.'s lumber products standards. Britain wants to obtain a broad supply base. Canada developed grading standards, etc. to facilitate the sale of its wood products abroad, while the U.K. approached standards as users seeking to develop a more sophisticated approach to building codes, and engineering standards. The result was a sophisticated set of wood products standards in the U.K. that was compatible with the needs of Canadian and other suppliers.

Although U.K. standards will not be adopted by the EC, the principles in the U.K. standards may be incorporated into the new EC standards, given that country's influence on the process. If the U.K. principles are adopted by the EC, Canada will be able to compete more effectively in the European market, since it will be able to benefit from extensive scale economies in shipping, production and marketing. ${ }^{12}$

\subsection{Environmental Regulation}

EC environmental regulations could have a significant effect on Canadian forest products producers in at least two ways. First, if a Canadian firm decides to establish a production presence in an EC country on a green-field basis or by acquisition of an existing firm, it will have to meet both national and EC-wide environmental regulations. Second, the Canadian firm's finished products may be subject to EC regulations ir the process by which they are produced is deemed environmentally unsatisfactory, i.e., the product itself may well meet EC standards, but it may be prohibited because EC regulators want to penalize the process by which it is made, e.g., because it may involve the production of dioxins. For example, concerns about the environmental

\footnotetext{
${ }^{10}$ Note that kiln drying is seen as a plant health issue. It is not part of the Eurocode process.

${ }^{11}$ The U.K. imports $83 \%$ of its lumber products and Canada is its largest supplier, supplying about one-third of the U.K. market, some 3 million cubic metres. Canada is also a major supplier of softwood plywood.

${ }^{12}$ In McKeen's (1990) view, it will be much easier for B.C. wood producers to penetrate the EC if there is one schedule of sizes acceptable in all 12 countries, one or more acceptable set of grading rules, one national technical/research body whose work will be acceptable throughout the EC, and if there are uniform testing and acceptance criteria.
} 
policies of nations from which forest products are imported have been expressed by home builders in the U.K. who are currently undertaking a study of products and materials used in the construction industry, specifically new housing, to assess the extent to which they could be termed "environmentally friendly"' (Harrington).

The Financial Post has noted that

The forest industry is also coming face-to-face with the clout of the Green movement. It is being queried by European importers on Canadian reforestation and cultivation practices. "Is Canada another Brazil?"' the industry is asked. "What is the Canadian exporter's pollution record?" "Does it dump dioxins?"' These questions are filtering through from the final consumers (December 25, 1989).

According to the Post, "the questions underline the need for Canadian business to be alert to social trends and public perceptions in Europe. The forestry industry is learning."

The problem for Canadian industry is more complex than simply meeting a single EC environmental standard. Within the EC, member countries can restrict the free flow of goods by adopting higher national environmental standards. The problem with environmental politics is the fact that internal competition between interest groups tends to lead to acceleration in demands. Consider for example pressures on timber imports to Europe. The extremists are advocating a boycott of all tropical timber imports into Europe from those countries unable to demonstrate sustained yield management. The Timber Trade Federation (TTF) has proposed a surcharge on all imported tropical timber products to fund the regeneration of hardwood forests in the supplying countries. The TTF has made this proposal in international forums and to EC political leaders. The concern about forest practices is now spreading to other countries. Environmentalists want to be assured that suppliers of forest products are practicing sustained yield management. Importers and sellers want to be seen as responsible corporate citizens by offering for sale products that are harvested under environmentally sound forestry regimes. Environmental protection measures are likely to be a major trade barrier, irrespective what trade regime is put in place.

Canadian firms should note that Scandinavian suppliers are promoting their products with reference to good forestry. Leading daily newspapers are advertising their raw material source as waste or "from countries practicing sustained yield forestry." 13 They should not underestimate the concern for the environment in some EC countries.

Obviously, the capacity of environmentalists to get their way will depend on not only the perceived political strength of the "Green" issue, but also on the anticipated consequences in terms of the higher environmental standards, e.g., on prices. This in turn will depend on the country's dependence on imports from countries unable to meet the environmental standards.

\footnotetext{
${ }^{13}$ External Affairs and International Trade Canada (1990) points out that "Canada's principal competitors for the EC import market, the Nordic countries (principally Sweden and Finland) have been forced to take the lead in developing and installing technology to reduce the fibre content of their products, reclaim effluent chemicals, and reduce pollution from pulping operations. Over the past decade, they have also consistently innovated to increase the value added to their products."
}

A particular problem for Canadian producers is that environmental regulation and forestry management practices are largely a provincial matter, with the rules varying by province. It is the provincial governments, therefore, who will have to take the lead in getting the point across that their regulations/practices are "environmentally sound".

Canadian producers and their domestic governments should expect to have to inform and lobby, possibly in several EC countries, to overcome potentially highly restrictive environmental regulations. Arguments against meddling in the internal regulatory affairs of another nation are likely to fall on deaf ears.

\subsection{EC Forest and Agricultural Policies on Land Use}

A new forest policy for the European Community has been proposed recently and published in the EC Official Journal (June 15, 1989). The policy is aimed at increasing the land dedicated to forestry in the Community and decreasing agricultural surplus lands. The policy is not an integral part of the Single European Act, but its implementation will be facilitated by the move toward a single market. The initiative contained in the policy document calls for subsidization of those EC farmers who will convert their land from agriculture to forestry. The policy also calls for heightened attention to forestry management and marketing. The subsidies promised in the document are aimed at several activities. These include reforestation, woodlands improvements, provision of infrastructure for forest protection, and construction of forest roads. The policy allows member states to supplement annually the income of farmers who convert their land to forestry on the basis of the number of hectares converted. Actual expenditures on afforestation can be subsidized to a maximum of ECU 1800 per hectare (more than twice the costs of reforestation in B.C.). The policy also permits the payment of an annual premium of ECU 150 per hectare for 20 years from the initial afforestation.

Roberts (1990) provides a detailed analysis of the implications of the policy for Canadian exports. He argues that to have an impact it would be necessary for the policy to provide sufficient inducements to landowners to convert land from agriculture to forestry, for the trees grown to be eventually cut, and for the harvested wood to be of the kind and quality that can compete directly or indirectly with Canadian products. The magnitude of the impact of the policy will depend upon the productivity of the land converted.

His analysis indicates that only marginal lands will be converted, in particular lands in Spain, Portugal and the U.K. Land converted in Iberia is likely to be planted with eucalyptus. The rotation time for eucalyptus is about 15 years and the fiber is mainly used for producing pulp. Other species would be planted in the more temperate zones with much longer rotation times.

Increasing demands for non-timber forest values will constrain the amount of trees that will be harvested in the future. The expectation of increasing environmental restrictions will prevent a significant amount of conversion to forestry unless the annual premium paid to forest landowners is large enough to compensate for the risks of losing a significant portion of the land value now associated with its option value (i.e., it is easier to convert agricultural land to other uses than forest land).

While the analysis indicates that the impact on the Canadian forest product sector of the specific proposal contained 
in the EC Official Journal may be limited, the principles articulated in the policy are a source of concern.

\subsection{Public Procurement Policies}

National governments purchased some ECU 530 billion worth of goods and services in 1986. This is equivalent to about $15 \%$ of the European Community's total GDP. If access to this market is liberalized, it could play an important role in stimulating European economic growth through greater competition. At present at least $75 \%$ of all national tenders go to domestic firms. The direct access to government procurement is not likely, however, to increase demand for Canadian forest products.

\subsection{Competition Policy}

The European Commission indicates that unification in 1992 will require the introduction of an EC merger control regulation. At the end of 1988 the Commission issued two new block exemptions dealing with franchise agreements and "know-how" licensing accords. These fill in important gaps in competition policy. When the merger regulations have been adopted, the Commission plans to issue guidelines on joint ventures.

Note that competition policy is the one area of Community legislation where the Commission can act without approval from the Council of Ministers. (In practice, however, the Commission does carry out extensive consultations with member countries and industry in this area and others). Regulations to control mergers, however, must be approved unanimously by the Council. A high degree of confusion is likely to remain for several years about who has authority and jurisdiction over which type of merger. These uncertainties stimulated many non-EC companies to move early and position themselves in Europe through mergers and acquisitions, preempting potential rivals within and outside the EC.

The importance of the competition policy to the forest products sector stems from its impact upon the rationalization process that is taking place within the EC and the Nordic countries, the constraints it may impose upon the globalization process of the Canadian forest product industry, and the possibility that competition law will be used as a means for imposing trade barriers. These impacts are discussed further in later sections of this paper.

\subsection{Market Growth, Competitors and EC- EFTA Relations}

\subsection{Anticipated Growth}

Perhaps the most promising opportunities that Europe 1992 offers exporting countries is the expected increases in demand. It is expected that the following factors will combine to increase European demand for softwood lumber:

- accelerated economic growth as a result of Europe 1992

- slow but positive population growth

- continued pressure on potential forestation sites by alternative uses

- uncertainty regarding the impact of acid rain on forest yields

- an increase in marketplace acceptance of wood over traditional building products such as brick, stone, etc. (EAITC 1990).
Chance factors, however, can influence significantly the opportunities for Canadian forest products firms. For example, in the winter of $1989 / 90$ severe winds damaged Western Europe's timber stands. In southern Germany, an estimated 50 million cubic metres of softwood lumber are lying on the ground and must be harvested. The result will be a glut of domestic production.

EAITC (1990) forecasts that the 53 million tonnes (t) of paper and paperboard produced in 1987 will increase to about 85 million $\mathrm{t}$ by the year 2010 . Even allowing for the high proportion of waste paper used in Europe (45-50\%), and increases in filler components, an additional 15-20 million t of paper-grade pulps will be required to meet the forecast levels of production.

Per capita consumption of newsprint in the EC ranges from $65 \mathrm{~kg}$ in Portugal to $200 \mathrm{~kg}$ in West Germany, but is still far below the U.S. level of $300 \mathrm{~kg}$. More rapid economic growth - which is now expected to be well above the level predicted in the Cecchini Report in 1988 - should stimulate consumption, particularly in countries of southern Europe which presently have a low level of consumption. Ambassador Molgat (1990) indicates that the European Commission estimates that the integration of East and West Germany will add one percentage point to the growth rate of the West Germany's economy in 1991 and at least one and one-half percentage points in 1992. Each percentage point increase in West Germany's growth rate adds 0.6 points to the EC's growth rate.

Not all of the increase in demand will benefit exporters to the EC. The pace of recent investments in new papermaking facilities has accelerated throughout the Community, but particularly in West Germany, the Netherlands, Belgium and the U.K., confirming the industry's growth potential.

\subsection{Competitive Suppliers}

Restructuring in recent years has made the paper industry in the EC more international, but also more concentrated and competitive (EAITC 1990). The gap in productivity and unit size between the EC and Nordic and North American mills is rapidly closing for key grades. In certain key grade sectors, such as coated graphic papers, the EC's productivity and average mill size is on a par with international competitors (EAITC, 1990).

As a whole, the EC is systematically short of fibre ${ }^{14}$ for paper making, although it is a leader in recycling so that virtually all of its packaging industry runs on secondary fibre (except for imported kraft liner). While parts of Europe's forests have been hurt badly by acid rain/air pollution, reforestation efforts have expanded to increase fibre supplies in the long term. In the short run, efforts to recover fibre from the damaged forests may create a jump in domestic supply. Further uncertainty has been created by the rapidly evolving situation in Eastern Europe and the Soviet Union (see Section 4).

For Canadian forest products firms the biggest EC volumes are in chemical pulp and newsprint. While pulp prices in the EC were very high in 1987-1989, Canadian producers must reckon with what are expected to be fairly modest rates of

\footnotetext{
${ }^{14}$ Roberts (1990) notes that the EC is about $52 \%$ self-sufficient in the supply of roundwood. The fraction ranges from $11 \%$ or $12 \%$ in the Netherlands and the U.K. to $90 \%$ in Spain and 366\% in Portugal.
} 
longer term growth. Further, Canadian firms must cope with EC efforts to reduce dependency on virgin fibre usage through (i) small-scale CTMP operations, (ii) recycled fibre separation units, (iii) increased use of eucalyptus (in Spain, Portugal, Brazil, and new countries) to offset long fibre, and (iv) heavy emphasis on the development of the Organosolv type of pulping processes which are claimed to be environmentally safe and small in scale (de Korver 1989).

De Korver (1989) groups the countries that compete with Canada in selling pulp and paper in the EC into four areas. First, there are the EFTA countries, for whom the EC is the only major, nearby market and is critical to their ability to justify the large capital investments they have made recently. However, Scandinavian firms face a shortage of fibre and high costs. Their response has been to integrate forward, produce a limited range of products and try to exploit all economies of scale. In these countries the forest industry accounts for up to $40 \%$ of GNP. Not only is EFTA seeking closer ties with the EC, but Scandinavian firms are investing heavily in new mills there.

Second, for American producers the EC is only one alternative among other target markets. Papermakers in the U.S. are investing primarily for their large home market. During bouts of excess capacity American producers have three options: sell in the Pacific/Far East market, sell in the EC, or temporarily cut back on output through shut downs. In general, the choice is based on considerations of short-run profitability. In any event, the U.S. is a major supplier of chemical pulp, kraftliner and some newsprint to the EC.

Third, the EC is supplied by Brazil which is producing pulp from eucalyptus trees. Brazil's mills benefit from an extremely low wood cost and attractive shipping rates to Europe.

Fourth, there are several new countries developing large pulp projects in Africa, Indonesia, Australia, and Chile. These will be coming on stream in the 1990s and their output will almost certainly find its way to the EC.

\subsection{EFTA-EC Relations}

Several of Canada's largest rivals in the supply of forest products to EC countries are members of EFTA, e.g., Sweden, Norway, and Finland. There are extensive formal and informal linkages between the EC and EFTA. The critical point for Canadian forest products companies is that some of their rivals in supplying the EC are already members of EFTA and thereby may have an advantage by reason of lower tariffs. For example, in the case of paper, Canadian mills face EC tariffs of 6-11\%, among the highest of any industrial sector, while rival Swedish, Norwegian and Finnish mills, as members of EFTA, benefit from a free-trade agreement between the EC and EFTA. These advantage may be greater after 1992, depending what new arrangements are negotiated between the EC and EFTA.

What might be the future of the EC-EFTA relationship after 1992? "EC Commission President Jacques Delors has posed two alternatives: the two trading blocs can continue with the same bilateral approach to relations, e.g., ECAustria, EC-Finland, which would eventually result in a huge free trade area; or EFTA can opt for its own internal consolidation and establish a bloc-to-bloc relationship, covering not only trade but also economics and politics"' (Canada, Dept. of External Affairs 1989).
On the whole, EFTA countries' policies can be regarded as " a broad attempt ... to create a dynamic European Economic Space (EES)... What is involved is a further extension of what is already the world's largest free-trade area" (Swedish Ministry for Foreign Affairs 1989). While current negotiations between EFTA and the EC deal with all the six freedoms (including labour movement), there is a resistance in several EFTA countries to several dimensions of these freedoms. For example, Finland, with its homogeneous population, has tended to resist agreements which will allow unrestricted population movements. Similarly, there is a strong negative sentiment in Finland with regard to the freedom to invest, especially in land. The traditional policies of neutrality in Sweden ${ }^{15}$ and Finland may constrain their willingness to join the EC as full members. Political reform in the Eastern bloc may lower domestic resistance to change in the policy of neutraiity. On the one hand, the change in the balance of power, the disintegration of the Eastern Bloc and the potential for its integration with Western Europe reduce the potential benefits of neutrality. On the other hand, exclusion from the EC or from a larger community which includes some or all of Eastern Europe would relegate EFTA countries to the position of satellite or fringe members, rather than core members of the European Community. In anticipation of an increasing integration, Sweden, for example, is aligning its regulatory and institutional structure with the changing framework in the EC to a position which will allow it, in the event of change in policy, to be integrated swiftly and with low transaction costs into the EC (Swedish Ministry for Foreign Affairs 1989).

The impact of Europe 1992 on the Swedish forest industry is likely to be beneficial whatever integration level is eventually chosen (Ohlsson 1989). The benefits to the forest products industry of complete integration are clear. Without complete integration, Ohlsson predicts that the forest products industry (mainly pulp and paper), as well as other capital intensive industries, while suffering in absolute terms from discrimination versus domestic ED firms, will continue to enjoy competitive advantages over non-European suppliers. In any event, he maintains that because these industries will not be discriminated against to the same extent as other Swedish industries, their comparative advantage will increase, leading to growth of about $2.5-3.5 \%$ as a result of Europe 1992. He expects some minor currency adjustments to facilitate such growth. (Complete integration with Europe would lead to $4-5 \%$ growth according to his analysis.) The impact for Finland's forest products sector is likely to be similar.

\subsection{The Potential Impact of Eastern Europe and the Soviet Union}

In the past 18 months, Eastern Europe has undergone an historic political transformation and is in the process of a comparable economic transformation. The economies of

\footnotetext{
${ }^{15}$ The Swedish Ministry for Foreign Affairs (1989) states that "Sweden's goal is to try to extend, and to become more deeply involved in cooperation with the EC at all levels in society, where this is compatible with Swedish neutrality policy." Bird (1989) suggests that "the Community is to Sweden what the United States is to Canada - the major market without which they could not survive." He indicates that Scandinavians are "making selective investments throughout Europe to establish a foothold within the Community and to forward integrate to the extent possible creating a natural customer for their home grown products."
} 
Eastern Europe, however, face some very serious problems:

- high foreign debt (notably Poland)

- low standards of living - even shortages of basic foodstuffs

- much disguised unemployment that will be made apparent when state enterprises have to face competition from within and without

- severe environmental problems that not only seriously debilitate the health of people in some areas, but will cost billions to overcome

- poor transportation and communications infrastructure

- pent-up demand for consumer goods

- official exchange rates that are far out of line with market rates

- foreign trade patterns dictated by political alliances at artificial prices.

Newsweek (March 12, 1990) suggests that "the goal of political union among the Twelve - 'little Europe' - is in danger of being swamped by a vast 'big Europe' mechanism centred on the relatively obscure 35-member Conference on Security and Cooperation in Europe (CSCE)... Some Western Europeans believe the Community will be obliged, eventually, to admit the East European countries as members." While this may take many years, East Germany entered the EC automatically when it united with West Germany. Apparently Jacques Delors, the head of the EC, believes the EC must complete its own ambitious agenda (single market, monetary union, and political integration) before it considers increasing its membership. Early in 1990 the Commission refused to consider the applications of Turkey and Austria for membership in the EC.

The EC commissioner for external relations favours a series of very extensive "second generation" association agreements including establishing free-trade areas, economic cooperation and various joint programs (e.g., on the environment, nuclear safety, and education). ${ }^{16}$ One of the models being mooted is that of three concentric circles with the present EC at the core. The second circle would be the six EFTA countries. The third circle would be Eastern European countries as well as Turkey, Malta and Cyprus. Another model is based on a series of regional organizations, e.g., Italy, Austria, Hungary and Yugoslavia have met to consider regional cooperation. Further, countries around the Baltic (Sweden, Finland, Lithuania and Estonia) are considering a loose, informal confederation.

While the Warsaw Pact and NATO continue to exist, their reason for being has been greatly undermined. As a result, new security arrangements are likely to be determined through CSCE (which was previously known as the Helsinki process).

Canadian firms need to know the potential balance between the increase in supply of wood or wood products to the EC from the accelerated harvest of forests in Eastern Europe that have been seriously damaged by acid rain and air pollution, and the pressures to export to gain foreign exchange and the increase in demands in Eastern Europe as a result of pressures to improve the standard of living.

The potential significance of Eastern Europe as a market is that if its 150 million inhabitants increase their

\footnotetext{
${ }^{16}$ See Newsweek, March 12, 1990, pp. 38-39.

${ }^{17}$ See "A Survey of Perestroika," The Economist, April 26, 1990.
}

consumption of paper by 10 kilograms per year, that is equivalent to the output from 10 relatively large paper machines (Benoit 1990). However, creating plants in these countries requires huge amounts of capital. Such investments at this time would require a major act of faith (Benoit 1990).

The impact of economic reforms in the Soviet Union on the short- and long-term supply of forest products in not clear. ${ }^{17}$ While there are about 8.11 million square $\mathrm{km}$ of forest in the Soviet Union, of which about $80 \%$ is softwood, the prospects of long-term economic wood supply are not clear. "The annual increment in the Soviet forests is estimated at 900 million $\mathrm{m}^{3}$. Felling is about forty percent of the increment"' (Magnusson 1989).

While wide areas are replanted, the incentive systems in place prevent tending, and a significant proportion of the replanted lands are not productive. The geographic dispersion of forests and the expense of effective reforestation efforts increase the cost of access to the resource. Indeed, economically accessible forest resources (e.g., Soviet Korelia) are overharvested and are expected to last only 25-30 years at current harvesting levels. Pressures are mounting to reduce annual harvest rates.

The reduction of harvesting in the west has been compensated by increased harvesting in the east. However, a shortage of transport capacity constrains the ability of the USSR to expand its wood supply and creates, despite the vast forest resources, shortages of raw materials for the forest products industry.

The logistic problems may be solved through joint ventures. For example, Doctus PLC, a British company, has signed an agreement with officials in the Soviet Union for the sole rights to extract some 48 million cubic metres of timber over the next 15 years. ${ }^{18}$ The deal, worth about $£ 2.6$ billion (Cdn $\$ 4.97$ billion) will add about $1 \%$ to the world's supply of timber. Doctus has organized a consortium of Austrian, British and Swedish buyers for the timber who will send machines and people to assist in the harvesting. The venture will also set up wood processing plants to permit the Soviet Union to export higher value-added finished products. Doctus will receive a fee of $12 \%$ for handling the exports of timber to Western Europe.

The Soviet Union's pulp and paper industry, as in other Eastern European countries, is outdated and wasteful. The USSR is the world's fourth largest producer of pulp and paper. There are 84 paper and board plants and 57 pulp mills in the country with production capacity of nine million tonnes of pulp and 11 million tonnes of paper and paper board per annum. Domestic consumption is $37 \mathrm{~kg}$ of paper and board per capita, per annum - a small fraction of the consumption of citizens in the West (e.g., in Sweden the consumption is about $243 \mathrm{~kg}$ ).

Numerous Soviet sources say that there is today a shortage of most paper grades in the country. The industry meets 70 percent of the demand for newsprint, 60 percent for board, and eight percent for soft, crepe paper. The shortages have been partially made up by imports. According to Soviet analysis, the cause of the shortages is insufficient technology and the low productivity of Soviet-made equipment"' (Magnusson 1989).

\footnotetext{
18“"British deal with Soviets will fell Siberian forest" Financial Post, April 4, 1990.
} 
A modernization effort may increase capacity and efficiency, but is constrained by a lack of capital. The pressure to secure foreign currency has forced the Soviets to export despite domestic shortages. Increasing domestic pressures for the higher standard of living in the next five years promised by perestroika will most likely constrain exports to gain hard currency is therefore not likely to be politically sustainable.

If economic reform is successful, one can expect great opportunities for investment and imports as the standard of living increases. The situation in other Eastern European countries is similar. However, in two countries, Poland and Czechoslovakia, which installed western equipment in the late 1970s and early 1980s, the renewal of capacity is more promising even without a surge of demand.

Investors considering joint ventures to take advantage of the low labour and raw material costs must, however, consider the costs of inadequate infrastructure (physical and financial). Most of the foreign investment appears to be based upon strategic consideration of preempting rivals rather than short-term profit.

In conclusion, the potential integration of Eastern European countries with Western Europe in our opinion is not likely to change the existing levels of forest product supply from the Eastern bloc to the EC, as increases in supply are likely to be matched by increasing domestic demand. Sharp but short-run fluctuations in exports and imports are likely, however, reflecting temporary changes in raw material availability (e.g., wood supply triggered as a result of salvage of damaged forests), financial demands and political needs.

\subsection{Effects of Strategic Behaviour within the EC}

The legal and administrative process that is called Europe 1992 is taking place in the wider context of "globalization" and a host of attendant and related changes in economic activity. Some of the most important changes include:

- rationalization of production

- increasing concentration in the industry structure through mergers, acquisitions and alliances

- changes in marketing and distribution channels

- intensification of research and development efforts

- preemptive investment in Europe by foreign companies.

\subsection{Rationalization}

The Canadian Department of External Affairs (1989) survey of 426 executives ${ }^{19}$ indicated that rationalization is the predominant structural effect expected in most sectors as a result of Europe 1992. The significance of large size in determining a firm's competitiveness in many cases is not simply a matter of having a world-scale plant producing standardized products. It is now more likely to be attributable to the ability of a large firm to co-ordinate production among more plants that are geographically dispersed so as to be able to meet diverse local (or perhaps national) demands. Further, in some cases, marketing, distribution and service costs are more significant than production costs. They too require coordination across sites and national boundaries.

However, in the manufacture of commodity products such as pulp and paper, many of the traditional ideas of economies of scale still apply.

\footnotetext{
${ }^{19}$ Some 164 were employed by U.S. and Canadian multinationals, 123 were in EC-based companies, 56 were in EFTA firms, and 14 were in Japanese and other firms.
}

These are capital-intensive sectors, dependent upon low-cost production and the ability to provide good standard quality. Plant locations may be governed by access to raw materials or cheap energy, but good international logistics and distribution in major European and international markets is a must. Many firms already meet these tests, but some must either expand further or concentrate on specific product lines (Canada, Dept. of External Affairs 1989).

With respect to the paper market, KNP vice-chairman Hans de Korver (1989) points out that despite the fact that the EC is a larger market than the U.S., most of its paper companies are smaller than those in the U.S. For example, Feldmühle, the largest paper producer in the EC, ranks only no. 21 on a global basis. His predictions concerning the restructuring that will follow Europe 1992 are as follows:

There is no doubt that there will be 8 or 10 large conglomerates in the European market with a turnover of $\$ 4-5$ billion and cash flows between $\$ 500$ million to $\$ 1$ billion. These will be able to continue the heavy investments at a level of $10 \%$ of turnover at acceptable risks. At the same time there will be conglomerates with a more diversified product mix and with different economic cycles in order to stabilise the profit picture. This process is already on its way... in Scandinavia as well as inside the EEC.

So the players are bigger and the markets [are becoming] more competitive due to "bulkification", product range differentiation and internationalisation (de Korver 1989).

\subsection{Mergers, Acquisitions, Joint Ventures and Alliances}

Industrial restructuring often takes the form of mergers and acquisitions, joint ventures and other types of corporate alliances. ${ }^{20}$ There are many different motives for engaging in mergers and acquisitions: to buy market share, to compensate for low internal growth potential in key business areas, to prepare for European integration, to meet competition from bigger U.S. firms, or simply to grow. Many non-EC firms favour the acquisition route as a way of building a solid base in the EC without adding to existing capacity and thereby possibly intensifying price competition. But the choice between buying or building depends greatly on the relative costs of these alternatives and the difference in time it takes to create a substantial firm (even with plenty of capital).

A trio of Swedish pulp and paper giants expressed various motives for their merger and acquisition activities.

The first, Svenska Cellulosa (SCA), is pursuing vertical integration to move toward higher value-added, consumer-related areas such as hygiene and packaging, and away from an overriding dependence on lower value, cyclically volatile products such as pulp. Says president Bo Rydin: "This new consumer orientation, highlighted by last year's acquisition of the French hygiene company Peaudouce, has been long in planning and will have an increasingly dominant position in SCA's long-term strategy."

\footnotetext{
${ }^{20}$ In 1988 there were 240 mergers/takeovers in the EC with a transaction value exceeding U.S. $\$ 100$ million (total value of U.S. \$135 billion). Some 101 were trans-Atlantic transactions (Bird 1989).
} 
The second, MoDo, has put together a series of domestic acquisitions, both horizontal and vertical (Holmen, Iggesund), with the objective of building a broadly based forestry group less susceptible to pulp price fluctuations and able to compete internationally. As chairman Matts Carlgren notes: "The Swedish forestry industry needs larger companies to meet competition, chiefly from the North Americans." The takeovers also increased MoDo's presence in EC markets, particularly the U.K. and Germany.

At the third, ASSI, a major restructuring program is designed to refocus the group within Europe ahead of 1992. As the corporate development director explains, this involves both acquisitions and disposals. But, he stresses, "1992 as such is not the driving force; it's competitive positioning." For example, ASSI in 1987 acquired a major British corrugated box company, and in 1988 it sold off a number of sawmills in Sweden. "It was a question of either putting a lot of money and effort into those businesses long term or of concentration, and we chose the road of concentration... So we have these three keywords in the company: packaging paper, corrugated boxes, and Europe as the home market" (Canada, Dept. of External Affairs 1989).

In addition, in April 1990 Stora Kopparbergs Bergslags AB, Sweden's largest forest products enterprise, reached agreement to purchase $85 \%$ of Feldmühle Nobel AG, a very large West German paper producer, for U.S. \$2.4 billion. ${ }^{21}$ Feldmühle had rejected Svenska Cellulosa AB's bid. Stora and Feldmühle have been cooperating in joint ventures for some two decades and Feldmühle is one of Europe's largest buyers of pulp. Stora is one of the largest producers of market pulp.

Structural changes within the European forest products industry (i.e., domestic suppliers) as a result of Europe 1992 depend on the answers to two questions. First, will there be an increase in domestic supply due to exploitation of economics of scale of existing plants (because there are no barriers within the EC)? Second, will there be mergers/takeovers involving EC firms and what form will they take - horizontal (within Europe, or by a foreign acquiror), or vertical (within Europe, or by a foreign acquiror).

\subsection{Changes in Marketing and Distribution}

As Europe becomes a single market after 1992, there will be strong pressures to co-ordinate marketing and streamline physical distribution. The pressures for centralization of decision making and unbundling activities to exploit regional comparative advantages will be high.

For example, the ways in which paper is distributed in the EC will change. At present, about $55 \%$ of total printing and writing paper in Europe is sold through merchants, and $45 \%$ sold directly by the producers. The only access for a papermaker to the medium and small size printers is through a merchant (wholesaler). The dependency on merchants varies, with close to $70 \%$ of volume in Germany sold through merchants, but only $20 \%$ in Italy. Then there is the matter of vertical integration. For example, in France close to $95 \%$ of the merchant capacity is controlled by papermills, while

\footnotetext{
${ }^{21}$ Pulp and Paper Week, April 30-May 4, 1990, Vol. 12, No. 17, p. 1.
}

in Germany virtually none is so controlled. According to de Korver (1989),

it is absolutely prohibitive to deliver goods across internal borders at the same service level and competitive cost as the inland merchants. The reasons are lost time at the border (certainly if the customs are working to the rule) and the cost of documents.

$\mathrm{He}$ concludes that because "the merchant infrastructure is completely settled", it is now "practically impossible to penetrate in this field". However, with the abolition of internal borders in 1992, "distribution will be regional across borders within a certain radius from a warehouse instead of the national distribution that is normal at present". This will require an extensive investment in infrastructure which EC paper producers are willing to make.

Distribution costs will depend on the pace of deregulation in transportation and EC efforts to push older methods of transport. For example,

Papermakers can expect, for example, Commissionled enthusiasm for distribution by train instead of truck, or combined transport. Deregulation of the industry, including the abolition of the practice whereby trucks are forced to return unladen from their delivery points, should mean a drop in haulage prices. Some move back to canal transport may be encouraged by EEC Commission proposals to subsidize a scrapping of old tonnage and the completion in 1993 of a major transEuropean canal link. The net results should be greater choice and lower costs for papermakers (Pulp and Paper International March 1989).

Despite the pressures for centralization of decision making, some niches within the forest products sector will continue to experience the effects of national segmentation. An ASSI executive, for example, thinks that national units will continue to be important.

Marketing of packaging paper to corrugated-box companies is still done on a country-to-country basis, except for some warehousing facilities which serve more than one country. We actually made an experiment of having marketing people hold responsibility for more than one country - a few individuals - and then we withdrew that because it didn't work very well. You know there are a lot of cultural differences, which make it imperative to be as local as possible. To have a marketing man in Hamburg go marketing paper in Holland - that's not a good idea today... "I think it takes a long time before you can create regional sales offices irrespective of national borders - a very much longer time than I expected when we ran that experiment 10 years ago." (Canada, Dept. of External Affairs 1989).

\subsection{Research and Development}

While the effect of Europe 1992 may be to increase the size of the export market for Canadian forest products producers, it will also very likely increase the intensity of competition within that market (and perhaps in others, if European firms become rivals in markets outside the EC, e.g., Japan). 
Expenditures on R\&D are seen as essential in efforts to escape from purely commodity production. The idea is to create new products or modify existing ones for new uses. At the same time, R\&D is necessary to find lower cost methods of making existing products or of making lowercost close substitutes through, for example, being able to make pulp from new fibre sources. Increased concern over pollution will also force greater spending on the development of products and processes which are "friendlier" to the environment.

Will R\&D efforts be accelerated by economics of scale in producing for a bigger market? Or will companies concentrate on achieving market control? A Finnish forest products executive put it this way:

We see that those two things really should go hand in hand, so you can't really separate them out. When you get a stronger position in the marketplace, you create more volume and that way you are able to invest more money in R\&D. When you do that, you improve your position in the marketplace. It's a circle (Canada, Dept. of External Affairs 1989).

Collaboration on R\&D activities is seen by many as a way of dealing with this problem. It is seen as a shortcut to critical mass in the research function. Over $40 \%$ of EC and EFTA firms surveyed expect to participate in joint projects under the R\&D programs. Companies will probably not seek to decentralize R\&D, but rather to develop multinational research teams.

\subsection{Foreign Direct Investment in the EC}

Firms now exporting to the EC may adopt the strategy of investing in Europe to ensure that they will be able to meet the more competitive market after 1992. They will be competing with increased cross-border investment by their rivals and customers.

In order to know about the ongoing changes within national markets in Europe as they become a single market, a firm needs to be physically and psychologically present within this market, and not just at one point in the EC. It is argued that

....it will definitely be increasingly important to be as "European" as possible in the post-1992 Single Market. No legal barriers will oppose non-European companies, but there will probably be a de facto preference for Europeans, whether in public procurement, R\&D or whatever (Canada, Dept. of External Affairs 1989).

EFTA companies are increasing exports to the EC but are also putting money into production, acquisitions and alliances with EC firms. At the same time, Scandinavian companies are not overlooking oppportunities in the rest of the world. For example, Tampella, a major Finnish producer of forest products as well as machinery, indicates that 1992 will not cause any diversion of investment funds to Europe:

Of course you need to have some prioritizing of your efforts. It's a question of what you do first. If you look at the whole group, some business areas are extending their operations in North America, like our boiler division or the pulp and paper machinery division, and others are looking more strongly for opportunities in the EC or stronger in North America, so we must select our strategy in that way (Canada, Dept. of External Affairs 1989).

But Sweden's Stora, Europe's largest pulp and paper company, and Kymmene, Finland's biggest forestry group, announced April 1990 that they had acquired equal joint ownership of Chapelle Darblay, France's dominant newsprint and magazine paper producer. The acquisition is part of Stora's strategy to expand its production in the European Community.

Canadian forest products have only a limited time in which to integrate their operations into the EC. Abitibi, Stone, MacMillan Bloedel, and Noranda are taking or have taken initiatives in this direction, positioning themselves as part of the EC industrial base. Further efforts toward globalization by Canadian companies will be to secure new raw material sources and preempt rivals in a world of resource limitations.

\subsection{Europe 1992 or Fortress Europe?}

While the 12 EC countries may well eliminate most or all of the national barriers to the free movement of goods, capital, people and services within the EC, the act of creating such a large internal market could also slow or stop the reduction in tariff and non-tariff barriers to trade between the EC and other countries such as Canada.

Whether producer or consumer interests will dominate in an EC member state depends on several factors. The first is whether the country is self sufficient (or a net exporter) in the various forest products, i.e., wood products (lumber, plywood, panel products), pulp, and paper (kraft, newsprint, fine paper, etc.). One would expect that if domestic firms supply virtually all of domestic consumption, and they have been protected, then producers are likely to dominate consumer interests.

Second, where imports constitute an important part of a country's supply of forest products, it is necessary to determine which are the supplying countries. At the very least it is necessary to know in which of the following blocs they can be found: other EC countries, Scandinavian countries (which are EFTA members), the U.S., or Canada. Because many matters in respect to Europe 1992 will be decided on the basis of the weighted voting system, ${ }^{22}$ it is important to determine the number of votes commanded by countries in which consumer or producer interests are likely to dominate.

The vice-chairman of KNP, Hans de Korver argues that Canadians ought not to worry about the possibility that Europe 1992 will turn into Fortress Europe. In his view, the concept "is a pure US invention dreamed up by people outside the EEC to get support for the approval of trade legislation meant to protect the 'fortress USA'."' De Korver (1989) contends that there are only three conditions to trade in the EC:

- EC producers should have the same access to the home markets of the exporter;

- it should be on the basis of fair trade without distortion of competition, which includes extreme effects of the parity of the currency; and

\footnotetext{
${ }^{22}$ Almost two-thirds of the proposed legislation stemming from the 1985 White Paper can be enacted by a "qualified majority," viz. 54 of 76 , votes based on the following allocation: France, Germany, Italy and the U.K., 10 votes each; Spain, 8; Belgium, the Netherlands, Greece, Portugal, 5 votes each; Denmark and Ireland, three each; and Luxembourg, two votes.
} 
- certain EC countries should be given the time to finish off their restructuring program.

A similarly positive view is offered by Canada's Department of External Affairs (1989): "so far there has been no concrete evidence of increased protectionism by the Community in the manufacturing or service industries - apart from Brussel's aggressive use of the antidumping weapon...,"23 However, U.S. industry in particular is concerned that, in many cases, the single market will introduce harmonized trade barriers which on average are higher than preintegration, individual country barriers. To the extent this happens, intra-EC trade will grow at the expense of North American exports.

\subsection{Corporate Strategies}

Europe 1992 represents both potential opportunities and threats for firms in the Canadian forest products industry. To a very large degree, they will not be able to affect the shape and characteristics of Europe 1992. That does not mean that Canadian firms cannot take actions that are likely to improve their position vis-à-vis the EC. Our review indicates that the following broad strategies should be examined by Canadian forest product firms:

- Maintain competitiveness by becoming more efficient and innovative.

- Move into new product areas that increase value-added and are less sensitive to fibre cost pressures and exchange rate uncertainty.

- Track the strategies adopted by Nordic competitors, including downstream integration of paper and board distribution outlets.

- Anticipate developments, e.g., environmental regulations, supply from non-traditional sources, accelerated harvesting of acid-rain damaged forests in the EC.

- Follow and adapt to developments in European legislation, e.g., product standards, certification and testing. Where adaptation is not possible, attempt to mobilize European consumers of your products to introduce changes in the proposed regulation.

- Evaluate EC investment opportunities to benefit from national treatment, e.g., entitlements re government procurement (EAITC 1990).

- Evaluate global investment opportunities to ensure access to raw material supplies and preempt potential rivals globally.

MacMillan Bloedel (MB) illustrates the range of involvement in the EC by a large Canadian producer. ${ }^{24} \mathrm{MB}$ 's direct involvement in the EEC, which is part of a strategy that dates back to the 1960s, includes the following: MB owns $30 \%$ of KNP, the largest light weight coated paper manufacturer in the EEC. It also has a subsidiary that distributes paper products at the wholesale level thoughout the EC. KNP has

\footnotetext{
${ }^{23} \mathrm{~A}$ prime example of such use of anti-dumping policy was the arbitrary floor price set for linerboard between 1983 and 1986. Any sale at a price below the floor price was deemed "dumping" without reference to actual market prices.

${ }^{24}$ The world's 35 largest forest products companies ranged inn size from $\$ 1.7$ billion to 14.0 billion in sales (1989). In this group, MacMillan Bloedel ranked no. 20 in 1989 with sales of $\$ 2.8$ billion. The nationality of the top 35 forest companies is as follows: U.S., 12; Nordic Countries, 7; Japan, 6; Canada, 5; Europe, 4; New Zealand, 1. The five Canada-based firms ranked nos. $15,20,22,26$, and 29.
}

been a good investment for $\mathrm{MB}$ and $\mathrm{MB}$ provides KNP with a shield against a hostile takeover bid. Of particular value to MB, KNP is a very loyal buyer of its pulp, produced mainly in its Harmac, mill at Nanaimo, B.C. Recently, KNP acquired a majority interest in Leykam Murzthaler, an Austrian producer of light weight coated paper and newsprint which acquires fibre from and sells paper to Eastern European countries, giving $\mathrm{KNP}-$ and indirectly $\mathrm{MB}-\mathrm{a}$ bridgehead in those countries. MB is also a $50 \%$ shareholder in a U.K. manufacturer of corrugated cartons that carries on business under the trade name U.K. Corrugated. Finally, MB continues to be a substantial exporter of pulp, lumber and plywood to arm's-length firms in the EC, operating through a distribution subsidiary in Brussels.

In a world where globalization means interdependence of geographically distant markets, few firms in the Canadian forest products industry can safely ignore Europe 1992. Indeed, it is clear that some Canadian firms have already undertaken strategic initiatives in anticipation of Europe $1992^{25}$ - but describing them would require another paper.

\subsection{Implications for Public Policy}

Europe 1992 and the Free Trade Agreement with the United States (which came into effect January 1, 1989) signal and symbolize very important changes that are having (and will continue to have) a profound impact on the Canadian economy. These changes include the globalization of production and distribution in many industries, the emergence of rival trading blocs, greater economic interdependence and growing awareness that nations (within and between economic blocs) are engaged in competition with each other. These and related changes raise serious questions about the nature of a wide range of federal and provincial public policies. In this section we explore some of these questions and offer some of our ideas about how some policies ought to be changed.

\subsection{A New Mind Set}

Public policies and changes in public policies begin with a change in ideas. The prevailing "conventional wisdom" must give way before there can be changes in government action. It is essential cabinet ministers and their senior policy advisors adopt a new mind set. The necessary new ways of thinking include the following.

First, it must be appreciated that nations (or regions within nations) are in a competitive struggle with each other individually or within trading "blocs"' and that public policies must reflect this fact. Nations compete with each other in a variety of ways - and all the signs point toward a greater degree of competition among nations. Nations compete for capital - to attract foreign investment (and retain that of resident firms) to increase the domestic rate, and they compete for immigrants, particularly those embodying valuable forms of human capital. Nations also compete in the marketplace of ideas, including the most fundamental ones about how a society ought to be governed and the means by which goods and services ought to be allocated. One has only to recall the recent peaceful revolutions in Eastern European

\footnotetext{
${ }^{25}$ An interesting example is the acquisition by Stone Containers, a large U.S. firm, of Consolidated Bathurst which has a large EEC container subsidiary, Europakarton. Thus, indirectly, Stone acquired a strong position in the EEC container market.
} 
countries. Nations compete in trying to raise the standard of living of their citizens. ${ }^{26}$ This form of rivalry has been greatly reinforced by omnipresent communications and the flows of international tourism which help to reinforce the metaphor of the "global village."

Competitiveness at the national level boils down to the ability of a country to raise the standard of living of its citizens relative to other nations, particularly those of which its citizens (particularly its elites) are aware. This requires improvements in productivity which implies innovations that create values, new products and services or ways of reducing the value of inputs per unit of output or both (Porter 1990; Ohmae 1990).

Second, large endowments of renewable natural resources only provide the illusion of wealth. ${ }^{27}$ They encourage a "we have a monopoly" mentality. However, the evidence is clear that more and more LDCs are capable of supplying basic commodities such as the fibre that is the primary raw material for pulp and paper. Vast supplies of natural resources also encourage a "rentier mentality", that there will always be a large economic rent left to the owners regardless of what is happening in the rest of the world. It is apparently extremely hard for most politicians and a very large fraction of the population to appreciate that tens of thousands of square miles of standing timber may have a net economic value of zero or even less. That is, the market value of the finished products (sold largely in highly competitive world markets) may not cover the costs of harvesting, transportation and processing - let alone leaving a generous rent for the owner (typically the Crown). Nature's physical bounty many not "translate" into an economic cornucopia. Moreover, the economic rent from such resources is the residual - hence it is determined largely by forces beyond the owner's reach (even if it is the Crown) and, more important, that rent is highly variable given the cyclical nature of the demand for the final products.

Third, political leaders and their advisors must appreciate wealth creation (including a fully-employed economy) depends not on more of the same, but on adding value as that value is (or comes to be) perceived by customers. Michael Porter (1990) contends that "national prosperity is created, not inherited. It does not grow out of a country's natural resource endowments, its labor pool, its interest rates, or its currency's value, as classical economics insists. ${ }^{28}$ Rather, "a nation's competitiveness depends on the capacity of an industry to innovate and upgrade" by raising product quality, adding desirable features and increasing production efficiency. In his view, "nations succeed in particular industries because their home environment is the most forwardlooking, dynamic and challenging"'.

Fourth, the need for more rapid and more extensive change is becoming all but ubiquitous - hence people and their government's policies must become more flexible and adaptable. Both must also try to anticipate and plan for change,

\footnotetext{
${ }^{26}$ Failure to take up the competitive challenge will almost certainly result in a decline in a nation's (region's) standard of living relative to rival nations that are more successful. Weaker competitor nations will tend to lose skilled and energetic people to others.

${ }^{27}$ Ohmae (1990) states that "having an abundance of resources has truly slowed down a country's development... In a truly interlinked, global economy, the key success factor shifts from resources to the marketplace, in which you have to participate to prosper. It also means people are the only true means to create wealth.",
}

not merely react to it in a nimble fashion. In trying to "protect" politically effective coalitions, governments inevitably create schemes that impose large costs on the productive efficiency of the economy directly and indirectly (e.g., by creating perverse incentives).

\subsection{Government Policy in a World of Blocs and Globalization}

With the completion of the process known as "Europe 1992 ," the European Community brings about a new international "negotiating game" among several large economic "blocs" (U.S. and Canada; Japan; EFTA; and possibly the Eastern European countries). Some of the general implications are as follows:

- Canada is required to put more "bargaining chips" on the table in each of the fewer sets of negotiations between or among blocs.

- Issues of particular importance to a particular industry, for example the forest industry, despite its lobbying efforts, may be traded away for benefits for other industries in Canada.

- The forest industry in Canada (and other domestic industries) may be adversely affected by bargains struck between other blocs, i.e., to which Canada is a third party.

In the world of "globalization" (whose effects are not the same for all industries and all countries) and large trade blocs, countries (and provinces) need to be aware that large firms are becoming less dependent upon any single country (bloc). Indeed, to strengthen large companies, countries (and provinces) need to allow/encourage these firms to diversify their operations across other countries so as to reduce risks, facilitate pre-emptive acquisition of important inputs at low cost, and gain/assure access to foreign markets.

Countries (and provinces) must better appreciate the interrelatedness of various public policies in terms of their effects on business enterprises. For example, in the forest industry a province's policies under which firms gain access to timber may figure in the import policies of a customer-nation where global environmental issues are highly salient.

Governments in Canada must more carefully consider the longer term implications of their regulatory and taxation initiatives on the international competitiveness of domestic firms and on the climate for foreign investment in Canada.

Canadian governments interested in the nation's economic welfare should pay more attention to the interests of consumers, and less to producer interests. Kenichi Ohmae (1990) argues that "the government's role.... is to ensure that its people have a good life by ensuring stable access to the best and the cheapest goods and services from anywhere in the world - not to protect certain industries and clusters of people." He goes on to emphasize that "every time governments try to protect resources, markets industries and jobs, they cost taxpayers dearly." Access to the "cheapest and best goods and services" also requires that a country be open to foreign investment - which also creates jobs as well as more goods and services for consumers.

\footnotetext{
${ }^{28}$ Porter's conclusions are based on a four-year study of "ten important trading nations." While Denmark, Korea, Sweden and Singapore were included, Canada was not. The ten represented $50 \%$ of total world exports in 1985. The industries included represented "the most important groups of competitive industries in the economy" (Porter 1990).
} 
Perhaps the best ways to "help" the Canadian forest products industry is to stop trying to do its short-run bidding, compensating for its managers' errors or doing the obvious things designed to improve its economic position (e.g., subsidies such as the pulp and paper modernization program in the $1970 \mathrm{~s}$ and $1980 \mathrm{~s}$ ). The federal government would be better employed creating a salubrious long-term climate in which it is easy to conduct productive economic activity in general. This means, among other things, not intervening to influence the exchange rate to offset export firms' cost disadvantages. It does mean, however, trying to smooth out macro economic gyrations by monetary and fiscal policies aimed at low inflation and the lowest practicable level of unemployment.

A favorable long-term climate requires taxation policies that favour longer-term capital investment in plant and equipment and in human beings. Michael Porter (1990) warns, however, that contrary to conventional wisdom, "simply having a general work force that is high school or even college educated represents no competitive advantage in modern international competition." He continues, "to support competitive advantage, a factor must be highly specialized to an industry's particular needs...'. Since the cornerstone of competitive advantage is innovation that leads to productivity gains, as a nation we must be prepared to regularly re-invest in human beings as they are required to acquire new specialized skills. Such skills, however, are likely to be easier to acquire if a large fraction of the labour force has a higher level of general education (knowledge of languages, mathematics and other basic sciences, analytic reasoning, communication skills).

In Porter's (1990) view, government's proper role in promoting the nation's competitive advantage is "as a catalyst and challenger" of private firms. Its role is "inherently partial," ${ }^{29}$ but it is important in "shaping the context and institutional structure surrounding companies and in creating an environment that stimulates companies to gain competitive advantage"' (Porter, 1990).

Porter (1990) offers a set of "simple, basic principles that governments should embrace..."

- Focus on specialized factor creation (e.g., specialized apprenticeship programs) as well as on such fundamentals as primary and secondary education, national infrastructure and health care.

- Avoid intervening in factor and currency markets ${ }^{30}-$ such actions are often counterproductive in the medium to longer run.

- Enforce strict product, safety and environmental standards; easing standards is counterproductive and tough regulations that anticipate new international ones give a nation's firms a head start in developing products that can be exported.

\footnotetext{
${ }^{29}$ Similarly, Ohmae (1990) argues that governments should be in the back seat, not the driver's seat. They should "make sure that their country is benefitting fully from the best-performing corporations and producers in the world, at the lowest possible cost to their people on a long-term basis." ${ }^{30}$ Ohmae (1990) notes that the foreign exchange market within the Triad (Japan, the U.S. and the EC) is some 100 times the size of the value of the trade in goods and services. As a result, the foreign exchange market has become "an end in itself. It obeys rules of its own and displays its own distinctive forms of behaviour." He notes that even when economic fundamentals in two nations change very little, there can be a $40 \%$ annual fluctuation in their exchnage rate.
}

- Sharply limit direct cooperation among industry rivals - even for the popular R\&D consortia. The object should be to stimulate proprietary research.

- Enforce a strong domestic antitrust policy - especially in respect of horizontal mergers and collusive behaviour; apply the same standards to foreign and domestic firms.

- Deregulate so as to encourage competition by reducing/eliminating entry barriers and regulated prices.

- Promote goals that lead to sustained investment in human skills, innovation and in physical assets. This means creating tax incentives for long-term investment, i.e., five years or more.

- Reject managed trade, e.g., orderly marketing agreements and voluntary restraints. These protect inefficient companies. Where trade barriers exist, concentrate on removing them, not on regulating trade.

These suggestions are both sound and highly relevant to both federal and provincial governments in Canada in regard to the torest industry. But more detail is required about public policy in B.C. in respect to the forest products industry.

\subsection{Provincial Policy}

About $80 \%$ of the capital invested in the coastal forest sector in B.C. is in converting plants. The large and growing capital intensity of such plants requires a secure supply of fibre (timber). As owner of over $94 \%$ of the forest land, the Province's policies as owner and regulator are crucial in determining the private firms' economic access to fibre. ${ }^{31}$ This means that a rational stumpage policy must reflect the dynamics of economic rents in what is a cyclical industry. It is unrealistic, therefore, as the B.C. government has sought to do, to attempt to collect a stable stream of stumpage revenues.

The Province must recognize that if more value is to be added to B.C. forest products, more investment in physical and human capital will be required. Incremental investment will only be forthcoming if there is a reasonable return on such investment. In general, it is not profitable to locate higher value-added activities close to the timber source unless there is a large local market (Polzin 1990). Adding value locally ${ }^{32}$ - regardless of cost - will reduce the net economic value of standing timber (owned largely by the Crown).

Even tighter woods recovery standards (that are under consideration in B.C.) will raise the cost of harvesting timber and in many cases require removal of logs from the forest at a cost above the value that can be recovered from them. In the short run, this will reduce the forest companies' margins. In the long run (only a few year), it will reduce the rent collected by the Crown as owner.

The Province faces an enormously difficult task of determining the appropriate level of investment in reforestation and related silviculture activities to produce the next

\footnotetext{
${ }^{31}$ The chairman of Weyerhaeuser has argued that it is of critical importance to forest companies "to be producing with the right balance of fiber availability and cost, and [to] be in a position to serve the world from the strongest raw material and production base" (Benoit 1990).

${ }^{32}$ The 1986 Census of Manufacturers indicates that for B.C. the valueadded per employee in logging was $\$ 54,000$ versus $\$ 135,500$ in pulp mills, $\$ 168,500$ in newsprint, $\$ 59,100$ in wooden doors and windows, and $\$ 94,500$ in corrugated boxes. Note that the wages and benefits in the B.C. forest products industry are about $\$ 50,000$ p.a.
} 
generation of forests. ${ }^{33}$ This is an enormously complex decision for several reasons. First, the time horizon is long - at least 40 years and possibly 80 years or so. Second, the market price of finished products is exogenously determined in world markets, and it is cyclical, therefore extremely difficult to predict. Third, the future costs of harvesting are highly uncertain; they depend on wage rates, the availability of new technology, and environmental constraints. Fourth, while the costs of replanting can be estimated fairly accurately, the appropriate level of subsequent expenditures on silviculture are much harder to determine with any degree of confidence. ${ }^{34}$ Fifth, there is much disagreement among both professionals and lay persons about the appropriate discount to be applied to estimates of future costs and revenues. Sixth, there is much disagreement about how to value nonmarket uses of the forest base (Stanbury et al. 1990).

The problem for the Province is not primarily a technical one. It goes to the heart of its basic values and in particular its attitudes toward the future. Decisions made "at the margin" in this case are likely to favor delaying or underinvesting in reforestation. Myopia may result in success at the polls, but it may prove to be economically very unsatisfactory in the longer run. In daily life, however, the long run is an abstraction; it is composed of a series of short runs (from a few days to a few years at best). At the same time, desire to "replicate" the forest that has just been cut down could easily result in overinvestment in so-called "intensive forest management", 35 .

Perhaps the most intractable political problem facing the provincial government is the rising public concern about the environment. These concerns affect the forest products industry in several ways. There are demands to stop the harvesting of certain stands of old growth timber (e.g., the Carmanah valley). These stands often have the highest gross value and would return the largest stumpage per unit to the Crown. There are demands for multiple uses of forest land. These tend to reduce limit harvesting volumes and increase costs. There are very vocal demands that pulp and paper mills reduce particular effluents (e.g., dioxins) to extremely low levels - regardless of the costs or the scientific evidence concerning their toxicity. Adam Zimmerman, chairman of Noranda Forest Products, notes that his firm will spend about $\$ 500$ million in the next three to five years cleaning up the liquid effulents of its mills on the B.C. coast. In his view, "the environmental imperative is now ahead of the economic imperative and we've got to respond' (Benoit 1990). There are demands to change clearcut logging practices that are aesthetically displeasing and are said to "devastate the ecosystem"' and also fail to fully utilize the wood available.

\footnotetext{
${ }^{33}$ Because of the grants it provides for such work, the federal government has a strong interest in this issue as well.

${ }^{34}$ For example, MacMillan Bloedel has analyzed more than 30 years of growth in 2000 plots established in second growth forests. These indicate that an excellent job of forest renewal after harvesting will produce forests with growth rates such that future harvests at ages between 50 and 150 years can be similar in volume to the average harvests in old growth over the past two decades.

${ }^{35}$ The benefits of quality or value improvement consequent upon spacing, fertilizing, thinning or pruning are somewhat nebulous. Although bigger trees may command higher prices, the constant march of technological change continually overtakes the apparent shortcomings of the "less valuable" logs. The pulping process is rather indifferent to tree size as are many of the processes used to make engineered wood products, e.g., oriented strand board or long wafer lumber. Products such as I-beams are replacing wide lumber in many structural applications. See Sedjo and Lyons (1990).
}

The effects of proposed changes in policy will be to raise costs substantially in some cases. There are demands for lower annual rates of cut to ensure sustained yields in physical terms regardless of the market value of the timber resource. There are pressures to expand or create new parks in which timber harvesting would be prohibited - so as to preserve the habitat for endangered species, to provide natural environments for the recreational pursuits of harried residents of large cities, and to have more trees to absorb carbon dioxide. In addition, there are demands that paper producers be required to use a certain amount of recycled paper in their furnish. On the consumption side, government departments and agencies are being pushed to use only recycled paper - regardless of the higher cost. As one forest industry executive has observed, "There are no more Paul Bunyans today. It's Johnny Appleseed all the way.",

Aggressive environmentalism in B.C. or elsewhere in North America is likely to push firms to invest abroad. Ironically, Third World countries could aggressively harvest their natural forests to be able to establish tree plantations whose growth cycle is a fraction of that of trees in the Pacific Northwest or B.C. For example, the loblolly pine grows two to three times as fast in Brazil as in South Carolina and the eucalyptus matures about 10 times as fast in Brazil as do pines in the U.S. (Benoit 1990).

\subsection{Constraints on Improving Public Policy}

Improving public policy is far more difficult than criticizing it. As critics of public policy we must recognize that intense competition in the political marketplace under the glare of omnipresent media coverage creates a high degree of "responsiveness" to the pressures of organized interests. With very few exceptions, government responses focus on short-run problems, and their actions often set in train inappropriate long-run responses (e.g., the dioxin "scare", in the B.C. forest industry has led to the commitment of huge capital expenditures on what is, from a scientific perspective, almost a "non problem"). Governments tend to focus on those problems "'pushed" by vociferous organized interests and that have high visibility in the mass media.

Often governments use their coercive powers to redistribute income in ways that are economically inefficient, but ones that meet political criteria. The result is a "serial potlatching game", which continues largely because of imperfect information, the ability of elites to manipulate symbols, and lags in information, cognition and action response. The motives for a wide variety of government interventions may be widely seen as laudable. The wider consequences are often perverse (particularly for allocative efficiency). Moreover, even the stated objective is seldom fully achieved - or if it is achieved the direct and indirect costs - if and when they are widely known - are so large as to make one ask if the game is worth the candle. The result is that even though all actors (voters, MPs, cabinet ministers, public servants, media) act in a locally rational and self-interested fashion, the result is a "system" of public policies that is rife with irrationalities and perversities. ${ }^{36}$

\footnotetext{
${ }^{36}$ The deeper reasons why this occurs in a democracy include the fact of representative government, the desire for stable but also responsive governments, imperfect and costly information, and positive and sometimes large transaction costs which give rise to the principal-agent problem between citizen/voters and their elected representatives, and the existence of quite frequent possibilities for "opportunistic behaviour" in the political system.
} 
Finally, one must recognize that while the internal political game constrains the ability of governments to pursue constantly and effectively the objectives of economic efficiency and long term growth, there are also increasing external constraints of government's policies. In the world of "economic blocs" and "globalization," the freedom of action of national governments may be severely constrained by multinational agreements or by threats of retaliatory actions of other nations. In the long run, however, this fact may not necessarily be harmful if governments recognize that there are limits on their ability to shape economic behaviour and leave more of the control of the playing field to market forces. Europe 1992 and the FTA may very well curb the tendencies of the Canadian governments to intervene in the marketplace.

\section{Acknowledgements}

We would like to acknowledge the information, insights and comments of the following experts: Guy D. Bird, Darcie Booth, Curtis J. Copeland, Celine Fittes, Denise Jacques, Earl L. Kelly, Lars Lönnstedt, Ken A. McKeen, Lennart Ohlsson, Jan Palmstierna, Don G. Roberts, Gary P. Scott, Peter Wattand Göran Wohlfahrt. Clearly the authors are solely responsible for the opinions and any errors in this paper.

\section{Bibliography}

Alan, L. 1988. "Jeux sans frontiers," The Economist, January 30. Albert, Michael and James Ball. 1984. Towards European Economic Recovery in the 1980s: Report to the European Parliament. Praeger Special Studies: New York.

Benoit, Ellen. 1990. "Forest Products a Global Report," Financial World, February 20. pp. 37-44 and pp. 67-72.

Bird, Guy D. 1989. "Presentation to the Quebec Lumber Manufacturers Association Annual Meeting, May 8" External Affairs Mission to the EC, Ottawa, Ont.

Blaser, Fred. 1989. “Altered EC rules offer opportunity”. Financial Post, November 10. p. 12.

Calingaert, Michael. 1988. The 1992 Challenge From Europe: Development of the European Community's Internal Market. National Planning Association, U.S.A.

Canada, Department of External Affairs. 1989. 1992: Implications of a Single European Market, Part 1: Effects on Europe. Department of External Affairs, April, Ottawa, Ont.

Cecchini, Paolo. 1988. 1992: The Benefits of a Single Market. Wildwood House, Aldershot.

Coffey, Peter, ed. 1988. Main Economic Policy Areas of the EEC - Towards 1992, 2nd edition. Kluwer Academic Publishers, The Netherlands.

Commission of the European Communities. 1985. Completing the Internal Market. White Paper from the Commission to the European Council. COM(85). June 14.

Commission of the European Communities. 1988. "Third Report from the Commission to the Council and the European Parliament on the Implementation of the Commission's White Paper on Completing the Internal Market."' Brussels: COM(88) 134. March 21.

Commission of the European Communities. 1989. Trade Policy Report. October 19, 1988.

Copeland, Curtis J. 1989. Letter to R.C. Harrington, Costain Homes (Central) Ltd., Milton Keynes, U.K., from the Canadian High Commission, London, September 20.

de Korver, Hans. 1989. "Europe 1992; Opportunities and Threats."' Speech to the CPPA 75th Annual Meeting, Montreal. Jan. 31- Feb. 3, 1989.
Drohan, Madelaine. 1989. "Canada hardly ready for a new Europe Inc.' Financial Post, February 13, pp. 1-4.

Drucker, Peter F. 1988. "Strategies for Survival in Europe in 1993'. The McKinsey Quarterly. Autumn. pp. 41-45.

EC Committee of the American Chamber of Commerce in Belgium. 1988. Business Guide to EC Initiatives (Brussels). Spring.

External Affairs and International Trade Canada. 1990. 1992 Implications of a Single European Market: Forest Products. Secretary of State for External Affairs, Ottawa, Ont.

Financial Times. 1988. "1992 - Countdown to Reality". February-March.

Friberg, Eric G. 1988. "The Challenge of 1992"'. The McKinsey Quarterly. Autumn. pp. 27-40.

Hall, Lynn. 1989. "Substantial progress made on European Unity". The Financial Post. July 27. p. 10.

Harrington, R.C. 1989. Costain Homes (Central) Ltd., Milton Keynes, U.K. letter to R.B. Gourlay, Canadian High Commission, London. September 8.

Hindle, Tim. 1988. "Europe's Internal Market: EEC 1992"' in The Economist. July 9 special issue - "A Survey of Europe's Internal Market."

Hindle, Tim. 1989. "Visions of 1992: The Single European Market" in The Europe Review: The Economic and Business Report, 4th edition. NTC Business Books, U.K.

Hunsicker, J. Quincy. 1989. "Strategies for European Survival"'. McKinsey Quarterly, Summer, pp. 37-47.

Jansen, Rolf Richard. 1990. "Is Size Important for International Competition?'” Paper presented at PRIMA, 21st Annual Conference "Accelerating Competition in a Global Market What Local Strategy?' Glasgow, April 18-20, mimeo.

Johnston, Catherine. 1989. "'Europe 1992: The Evolving Dynamic,' Global Business Issues. Vol. 1(2). International Business Research Centre, Canada.

Jolly, Stephen. 1990. "Lobbying in the global marketplace". Atlantic: Journal of the American Chamber of Commerce (U.K.). February. pp. 14-15.

Lake, David. 1989. “Europe's New Dealmakers”. Canadian Business. July. pp. 28-31, 48-50.

Magee, John F. 1989. "1992: Moves Americans Must Make”. Harvard Business Review. May-June. pp. 78-84.

Magnusson, Marina. 1989. "Unique Report on Soviet Forestry: A Gigantic Industry With Major Problems". Scandinavian Pulp and Paper Magazine. No. 2. May, pp. 54-68.

McKeen, K.A. 1990. "'Speaking Notes"' for a Presentation to the Europe 1992 Conference, Vancouver, B.C. February 26. mimeo. Vancouver: COFI.

Minshull, G.N. 1985. The New Europe: An Economic Geography of the EEC. Hodder and Stoughton, London.

Molgat, David. 1990. "Speech to the Council of Forest Industries of British Columbia, Vancouver April 20". mimeo.

Office for Official Publications of the European Communities. 1988. Europe Without Frontiers - Completion of the Internal Market. European Documentation periodical 3/1988, Luxembourg, March.

Office for Official Publications of the European Communities. 1988. "The Economics of 1992". European Economy Series. No. 35. March.

Ohlsson, Lennart. 1989. "Swedish Industry and the EC in the Nineties". Stockholm: Federation of Swedish Industries. October.

Ohmae, Kenichi. 1990. The Borderless World: Power and Strategy in the Interlinked Economy. Harper Collins Publishers, New York.

Overton, David. 1983. Common Market Digest: An Information Guide to the European Communities. The Library Association, London.

Padoa-Schioppa, Tommaso. 1988. Efficiency, Stability and Equity: A Strategy for the Evolution of the Economic System 
of the European Community. Oxford University Press, Oxford.

"Paper makers fear new EC barriers in 1992', Globe and Mail. February 1, 1989. p. B10.

Pelkmans, Jacques. 1988a. "A Grand Design by the Piece?" in Roland Bieber et al. (eds.) 1992: One European Market? European University Institute, Florence.

Pelkmans, Jacques. 1988b. “An Enterprising Community”. SAIS Review. January.

Pelkmans, Jacques and Alan Winters. 1988. Europe's Domestic Market. Royal Institute of International Affairs Chatham House Papers No. 43. London: Routledge, London.

Pelkmans, Jacques and P. Robonson. 1987. "The Aspirations of the White Paper'. Journal of Common Market Studies. Vol. 25(3). March. pp. 181-192.

Philip, Alan Butt. 1988. Implementing the European Internal Market: Problems and Prospects. Royal Institute of International Affairs, Discussion Paper No. 5.

Pitts, Gordon. 1989a. "Growing concern over new product standards". The Financial Times. June 27. p. 12.

Pitts, Gordon. 1989b. "Fresh opportunities for Canadians". Financial Post. June 28. p. 10.

Pitts, Gordon. 1989c. "Canadian banks can seek new opportunities', Financial Post. June 29. p. 14.

Pitts, Gordon. 1989d. Rules on labor may be a problem in the new Europe',. Financial Post. June 30. p. 12.

Polzin, Paul E. 1990. "The Spatial Distribution of the Wood Products Industries". University of Montana.

Porter, Michael E. 1990. "The Competitive Advantage of Nations". Harvard Business Review. March-April. pp. 73-93.

Pryce, R. ed. 1987. The Dynamics of European Union. Croom Helm, London.

Roberts, Don G. 1990. “The European Community's Proposed Forestry Policy: Implications for Canadian Exports?" Ottawa: Forest Sector Analysis Division, Economics and Statistics Directorate. Forestry Canada. March. Working Paper.
Sanders, John. 1989. "Mr. Europe' enters the forest industry". Scandinavian Pulp and Paper Magazine. No. 2. May. pp. 9-12.

Schrewelius, Marie. 1989. "Technical Barriers to Trade - Testing and Certification Policy in Europe - General Product Safety - Improvement of the Exchange of Goods and Trade for the Paper and Board Converting Industry'. Paper presented to the CITPA meeting in Lisbon. September 14. mimeo.

Sedjo, Roger A. and Kenneth S. Lyons. 1990. The Long-Term Adequacy of World Timber Supply. Resources for the Future, Washington, D.C.

Stanbury, W.T., Ilan Vertinsky and H. Thille. 1990. "The Use of Cost-Benefit Analysis to Allocate Forest Lands Among Alternative Uses"'. Forest Economics and Policy Analysis Research Unit, University of B.C. September. mimeo.

Straetz, Robert. 1989. "U.S. Exporters Should Find That Benefits of 'Europe 1992' Program Will Outweigh Problems'. Business America. pp. 10-11.

Sunley, J.G. 1989a. "European Standards on Timber: Progress Report'. BSI Standards, London. August.

Sunley, J.G. 1989b. "European Standards on Timber - Progress Report December 1989', BSI Standards, London. December.

Swedish Ministry for Foreign Affairs. 1989. "'Sweden and West European Integration: Spring 1988 - March 1989”. Unofficial translation of the conclusions from the report Sweden and West European Integration. Description of the Integration Effort Spring 1988 - March 1989. Regeringskansliets Offsetcentral, Stockholm. August.

Union Bank of Switzerland. 1989. The EC Internal Market: The Challenges and Opportunities for Switzerland. Department of Economic Research, Union Bank of Switzerland, Zurich.

Western European Economic Handbook. 1987. Euromonitor Publications Ltd., London.

\section{Membership Dues 1991-1992}

\footnotetext{
Active Membership

1st and 2nd year after graduation (grad 1990, grad 1991)

Other new members for first year

Married or equivalent, second member only

All other active members

Other Memberships

Members having retired status, prior to 1990-91

who wish to receive the Forestry Chronicle

Members having retired status, prior to 1990-91,

who do not wish to receive the

Members granted retirement status subsequent to $1989-90$

Student Members

Sustaining Individuals (CIF Members)

Sustaining Corporate
}

\section{National \\ Dues}

$\begin{array}{ll} & \text { AL } \$ 8.00 \\ \$ 82.00 & \text { CC } \$ 8.00 \\ \$ 82.00 & \text { CH } \$ 8.00 \\ \$ 82.00 & \text { CO } \$ 10.00 \\ \$ 114.00 & \text { CR } \$ 8.00 \\ & \text { LW } \$ 13.00 \\ \$ 36.00 & \text { MB } \$ 10.00 \\ & \text { MR } \$ 00.00 \\ \$ 0.00 & \text { ND } \$ 10.00 \\ & \text { NO } \$ 5.00 \\ & \text { NS } \$ 10.00\end{array}$

$\$ 36.00$

$\$ 36.00$

$\$ 38.00$

$\$ 240.00$

\section{Section Dues}

AL $\$ 8.00$
$C C \$ 8.00$
CH $\$ 8.00$
CO $\$ 10.00$
$C R \$ 8.00$
LW $\$ 13.00$
MB $\$ 10.00$
MR $\$ 00.00$
ND $\$ 10.00$
NO $\$ 5.00$
NS $\$ 10.00$

NW $\$ 12.00$
Students $\$ 5.00$
OK $\$ 5.00$
OR $\$ 7.00$
OV $\$ 16.00$
PA $\$ 8.00$
RM $\$ 10.00$
SK $\$ 10.00$
SN $\$ 8.00$
SO $\$ 20.00$
Students $\$ 20.00$
VA $\$ 10.00$
VI $\$ 5.00$

Upon written application, spousal members of Active Members, may have the dues of one of them reduced by an amount determined annually. Spousal members are members of the same Section who are living together as spouses and using the same mailing address.

The Institute year runs from July 1 to June 30. Applications dated after January 1 will be charged half dues for that Institute year. Applications dated after April 1 will be charged no dues for that Institute year. 